\title{
Tinjauan Filosofis tentang Epistemologi Usul Fikih Berbasis Metode Jama'i
}

\author{
Hasan Bisri \\ Universitas Islam Negeri (UIN) Sunan Gunung Djati Bandung \\ Email: hasanbisri@uinsgd.ac.id
}

\begin{abstract}
ABSTRAK
Artikel ini berusaha menawarkan metode jama'i sebagai salah satu epistemologi ushul fikih. Tawaran itu didasarkan pada pemikiran bahwa usul fikih secara filosofis mengandung beragam pandangan. Paling tidak, bila dilihat dari sudut epistemologis. Epistemologi yang berkembang dalam perjalanan intelektual umat Islam tidaklah sesederhana yang dibayangkan orang. Dalam perkembangan akhir-akhir ini, nampaknya epistemologi usul fikih kurang diperhatikan atau bahkan ingin dicampakkan dengan alasan ketakutan akan kehancuran usul fikih itu sendiri, paling tidak ia tetap mendapat sambutan cukup meriah dari para pakar fikih. Dengan demikian, menjadi sangat wajar ketika para pengkaji usul fikih di berbagai perguruan tinggi Islam, dituntut untuk senantiasa berinovasi dan mengeksplorasi gagasan tentang usul fikih sebagai logika Islam. Dalam artikelnya ini, penulis menawarkan epistemologi Jama'i.
\end{abstract}

\section{ABSTRACT}

This article attempts to offer the jama'i method as one of the epistemologies of ushul figh. The offer is based on the idea that the fiqh proposal philosophically contains various views, at least from an epistemological point of view. The epistemology that develops in the intellectual journey of Muslims is not as simple as people imagine. In recent developments, it seems that the epistemology of the fiqh proposal has received little attention or even wants to be dumped on the grounds of fear of the destruction of the fiqh proposal itself; at least, it still gets a reasonably enthusiastic response from fiqh experts. Thus, it becomes very natural when the reviewers of fiqh proposals in various Islamic universities are required to constantly innovate and explore the idea of fiqh proposals as Islamic logic. In this article, the author offers Jamaican epistemology.

Keywords: Epistemology, jama'i method, ushul al-fiqh 


\section{PENDAHULUAN}

Hukum Islam menghadapi tantangan lebih serius selaras dengan perubahan sosial dan budaya yang begitu deras, terutama pada masa sekarang ini, berupa cepatnya kemajuan ilmu pengetahuan dan teknologi. Untuk menjawab berbagai permasalahan baru yang berhubungan dengan hukum Islam, para pakar hukum Islam tidak bisa lagi hanya mengandalkan ilmu tentang fikih, hasil ijtihad di masa lampau. Alasannya, karena warisan fikih yang terdapat dalam kitab-kitab klasik tersebut, bukan saja terbatas kemampuannya dalam menjangkau masalah-masalah baru yang belum ada sebelumnya, tetapi juga terdapat pendapat-pendapat ulama yang kurang relevan dengan masa sekarang ini. Oleh karena itu, umat Islam perlu mengadakan penyegaran kembali terhadap warisan fikih, dan yang paling penting lagi agar mampu menemukan rumusan-rumusan baru fikih dalam rangka memberikan jawaban terhadap masalah-masalah yang muncul sekarang ini yang belum ada dalam kitab-kitab lampau. Dalam konteks ini, ijtihad menjadi sebuah kemestian dan metode ijtihad mutlak harus dikuasai oleh para ulama fikih yang melakukannya. Metode ijtihad inilah yang dikenal dengan usul fikih.

Usul fikih, sebagai salah satu diskursus penting dalam kajian keislaman telah muncul dan berkembang seusai dengan agama Islam (Khallaf, 1978:23). Sebagai salah satu produk aktivitas intelektual para pakar fikih, ia dengan sendirinya mengandung berbagai pandangan yang bisa berbeda bahkan bertolak belakang, sesuai dengan latar belakang masingmasing tokoh, walaupun dasar pengambilannya itu sama. Sesuai dengan pengertian awal terma fikih itu sendiri yaitu pengetahuan dan pemahaman (Al-Ghazali, 1971:11), maka kajian usul fikih sarat dengan istilah, proses, dan tujuan pengetahuan yang dalam dunia filsafat dikenal dengan istilah epistemologi.

Epistemologi dalam dunia filsafat paling tidak membicarakan tentang hakikat pengetahuan, sumber pengetahuan, dan cara memperoleh pengetahuan. Epistemologi menurut Runes adalah the branch of philosophy which investigates the origin, setructure, methods and validity of knowledge (Halmyn 1972:-9). Itulah sebabnya ia sering disebut dengan filsafat pengetahuan karena epistemologi pada dasarnya adalah cabang filsafat yang membicarakan tentang pengetahuan manusia (Titus, 1984:187).

Kaitannya dengan tema tulisan ini, yakni Epistemologi Jama'i Sebagai Epistemologi Ushul Figh: Sebuah Tinjauan Filosofis, maka dengan sendirinya pembahasan tentang pengetahuan yang relevan adalah pengetahuan filsafat. Namun demikian, mengingat usul fikih berkaitan erat dengan teks-teks doktrinal dari sebuah agama, maka dengan sendirinya pembahasan ini juga menyinggung pengetahuan mistik. Di samping itu, usul fikih bukanlah ilmu yang tidak bisa diterapkan dalam kehidupan nyata atau empirisasi, maka dengan berat hati pembahasan ini juga menyerempet pengetahuan sains. Dengan kata lain, tulisan ini tidak bisa hanya berfokus pada satu jenis 
pengetahuan sebagai disebutkan di atas, akan tetapi akan menyinggung seluruhnya dengan porsi terbesar pada pengetahuan filsafat.

\section{METODE}

Kajian ini menggunakan metode kajian pustaka (literature review). Dalam penelitian ini, tinjauan pustaka adalah survei sumber ilmiah tentang topik epistemologi hukum Islam untuk memberikan gambaran umum tentang perkembangan pemikiran epistemologi hukum Islam saat ini.

\section{HASIL PENELITIAN DAN PEMBAHASAN}

\section{Ranah Epistemologi Secara Umum}

Sebagaimana dikemukakan di atas, berbicara tentang epistemologi, dengan sendirinya harus membicarakan tentang hakikat pengetahuan, sumber pengetahuan, dan metode memperoleh pengetahuan. Ranah pertama yang menjadi kajian epistemologi adalah apakah hakikat pengetahuan itu . Secara umum dipahami, pengetahuan adalah semua yang diketahui. Menurut Jujun S. Suriasumantri, pengethauan adalah sebuah produk dari suatu proses kegiatan mental berupa berpikir (Suriasumantri, 1997:37).

Dalam masalah hakikat pengetahuan, terdapat dua teori yang saling melengkapi, yaitu teori idelisme dan teori realisme. Pertama, teori idealisme merupakan sebuah teori tentang hakikat pengetahuan yang didasarkan pada pemahaman bahwa hakikat dari segala sesuatu adalah jiwa atau ide, bukan materi. Dengan kata lain, jiwa di alam semesta ini menduduki posisi sentral. Teori ini untuk pertama kalinya di kemukakan oleh Plato yang terkenal dengan gagasan pemikirannya tentang mite gua (Hadiwiyono, 1991:42). Kedua, teori realisme. Teori ini didasarkan pada pandangan yang mengatakan bahwa hakikat segala sesuatu di alam ini adalah bendabendanya sendiri yang riil (being is being) dan bukan berada di dalam ide (Kattsof, 1989:111). Teori ini oleh para ahli filsafat dikembalikan kepada pandangan Aristoteles dan filosof Yunani lainnya yang mengatakan asal dari segala sesuatu adalah sesuatu yang bersifat materi, misalnya Thales dan Anaximandros. Kedua teori ini juga menimbulkan perbedaan sifat dasar pengetahuan. Karena hakikat pengetahuan di dasarkan pada sesuatu yang bersifat abstrak (ide, jiwa, spirit), maka sifat dari pengetahuan dari teori idealisme adalah subyektif. Artinya, pengetahuan sangat ditentukan oleh jiwa dan ide yang ada dalam diri seseorang. Sebaliknya, teori realisme yang didasarkan pada sesuatu yang bersifat konkret (misalnya: air, udara, tanah, proses, dll), maka lebih bersifat obyektif (Bachtiar, 1987:38).

Pembicaraan selanjutnya adalah sumber pengetahuan. Berkaitan dengan sumber pengetahuan ini, telah muncul beberapa aliran yang 
semuanya memiliki kelebihan dan kekurangan. Pertama, rasionalisme, yaitu aliran epistemologi yang berpendapat bahwa sumber dari seluruh pengetahuan manusia adalah rasio atau akal. Pandangan ini banyak terinspirasi oleh pemikiran Rene Descartes. Semboyan yang terkenal darinya adalah cogito ergo sum (aku berpikir maka aku ada). Dalam menyusun sebuah pengetahuan harus dimulai dari aksioma yang diturunkan dari ide yang tegas, jelas, dan pasti. Baginya ide yang valid adalah ide yang jelas dan terpilih secara tegas (clear and distinc) (Hadiwiyono, 1991:19). Kedua, empirisme, yaitu aliran epistemologi yang berpendapat bahwa sumber pengetahuan adalah pengalaman panca indera. Tokoh yang membidani teori ini adalah John Locke yang terknal dengan teori Tabula Rasa-nya. Akal baginya bersifat pasif, ketika pengetahuann diperoleh. Artinya rasio atau akal bagaikan sebuah kertas kosong yang sangat dipengaruhi oleh pihak luar (pengalaman inderawi). Pengalaman disini bisa bersifat lahiriah (sensation) ataupun batiniah (reflection) (Tafsir, 1997:21). Ketiga, intuisionalisme, yaitu aliran epistemologi yang meyakini bahwa sumber pengetahuan adalah intuisi yang bersifat ruhani. Hendri Bergson (1859-1941) adalah tokoh aliran ini. Tokoh yang berkebangsaan Prancis keturunan Yahudi ini menganggap tidak hanya indera yang terbatas, akal juga terbatas. Obyek-obyek yang kita tangkap itu adalah obyek tersebut tidak pernah tetap atau konstan. Akalnya juga terbatas, karena akal hanya mampu memahami obyek bila ia mengkonsentrasikan dirinya pada obyek. Akal hanya mampu memahami bagian-bagian dari obyek, kemudian bagian-bagian tersebut digabung-gabungkan oleh akal (Kattsof, 1989:145). Hal ini jelas berbeda dengan pengetahuan secara menyeluruh tentang obyek tersebut. Misalnya istilah sejahtera. Barangkali seseorang bisa mengatakan orang lain sejahtera, sehingga timbul pemahaman tentang sejahtera. Akan tetapi belum tentu orang lain itu sejahtera karena dia memiliki pemahaman yang berbeda tentang sejahtera. Dengan kata lain sejahtera secara rasional tidak bisa dipastikan definisinya. Akal dan intuisi, lanjut Bergson, memiliki orientasi yang bertentangan. Akal (intellect) adalah alat yang dipakai sains untuk menghadapi materi dalam hubungan kuantitas, sedangkan intuisi adalah naluri (instince) yang menjadikan kesadaran diri sendiri dapat menuntun kepada kehidupan internal. Sebagai akibatnya pengetahuan terbagi menajdi tiga bagian, yaitu pengetahuan intelektual, pengetahuan intuisi, dan pengetahuan diskursif (Tafsir, 1991:24). Dan keempat, dialektika antara rasionalisme dan empirisme. Aliran ini berpandangan bahwa sumber pengetahuan adalah dari akal dan pengalaman inderawi secara simultan. Beberapa tokoh yang membidani aliran ini adalah Immanuel Kant dan Karl Rayemond Popper. Aliran ini muncul ketika kedua tokoh di atas melihat kekurangan dan kelebihan dari masing-masing aliran (rasionalisme dan empirisme). Dengan kata lain, kelemahan pada kedua aliran di atas dieliminir, sementara kelebihannya di maksimalisir (Taryadi, 1991:25). 
Selanjutnya, manusia dalam upaya untuk memperoleh pengetahuan telah menggunakan berbagai cara. Sesuai dengan perkembangan sejarah manusia, metode yang digunakan dalam memperoleh pengetahuan mengalami gradasi yang cukup unik. Pertama, manusia memperoleh pengetahuan dengan cara melihat, mendengar, membau, dan memegang. Setelah manusia mengindera sesuatu yang dilanjutkan dengan mengetahui sesuatu tersebut, maka muncul metode empirisme. Karena empirisme itu sendiri berarti pengalaman dari kata Yunani empeirikos dari kata dasar empeiria. Metode kedua adalah dengan menggunakan akal yang mampu memahami sesuatu yang lebih tinggi. Istilah-istilah abstrak, konsep, ide dan sebagainya hanya dapat diperoleh dan diterima melalui akal atau rasio. Pengalaman tidak mampu memperoleh dan mengolah sesuatu yang bersifat absrak atau konsep-konsep atau bahkan ide-ide yang sederhana sekalipun. Dan metode yang ketiga adalah manusia menggunakan hati nurani dan alatalat indera dalam memperoleh pengetahuan. Jadi secara singkat dapat dikatakan, metode yang digunakan mausia dalam memperoleh pengetahuan adalah dari pengalaman indera lahir (empirisme), akal (rasionalisme), dan rasa atau indera batin (intuisionisme) (Tafsir, 1991:14).

Bila melihat hakikat, sumber, dan metode memperoleh pengetahuan di atas, secara umum sebagaimana dikatakan Ahmad Tafsir, pengetahuan dapat dikelompokan menjadi tiga. Yaitu pengetahuan mistik, pengetahuan filsafat, dan pengetahuan sains. Ketiganya merupakan jenis pengetahuan yang ada dari zaman Yunani sampai zaman modern ini. Meskipun pada awalnya belum terklasifikasi secara baik. Namun memasuki zaman renaissance, pengkategorian pengetahuan menjadi tiga semakin jelas. Pertama, pengetahuan mistik merupakan pengetahuan yang pertama kali muncul dalam sejarah manusia. Pengetahuan ini memiliki obyek yang abstrak supralogis atau metarasional, menggunakan paradigma mistis. Metode yang digunakan untuk mencapai pengetahuan ini adalah dengan latihan atau meditasi. Adapun kebenarannya ditentukkan oleh rasa atau dzauq. Kedua, pengetahuan filsafat memiliki obyek abstrak tapi logis. paradigma yang digunakan adalah paradigma logis, metode yang digunakan adalah metode rasio atau pemikiran. Adapun kebenarannya diukur dengan apakah pengetahuan tersebut logis atau tidak logis. Dan ketiga, pengetahuan sains memiliki objek sains, menggunakan paradigma positif, metode yang harus digunakan adalah metode ilmiah (scientific method), dan kebenarannya diukur apakah pengetahuan tersebut logis dan terbukti secara empiris atau tidak (Tafsir, 1991:30).

Pengetahuan yang dianggap benar atau valid dapat dilihat dari tingkat koherensi, korespondesi, dan pragmatisnya. Dengan kata lain, untuk menguji dan mengukur sebuah ide filosofis itu benar atau tidak terdapat tiga teori yang di kembangkan para filosof. Pertama, teori koherensi (the coherence of the truth). Kebenara pada dasarnya terwujudnya konsintensi dan keharmonisan dari seluruh pernyataan. pernyataan dalam berbagai 
tingkatannya harus bersifat konsisten dan harmonis. Artinya seluruh pernyataan tersebut merupakan sebuah susunan yang berhubungan secara sistematik, sehingga ide yang tidak masuk akal akan tertolak. kedua, teori korespondensi (the correspondence theory of the truth). Kebenaran adalah pernyataaan yang memiliki kesetiaan tinggi terhadap realitas objektif. Dengan kata lain, kebenaran adalah kesesuaian antara pernyataan dengan fakta itu sendiri. Dan ketiga, teori pragmatis (the pragmatic theory of truth). Kebenaran menurut teori ini adalah terletak pada seberapa fungsionalnya kebenaran tersebut dalam kehidupan praktis. Teori ini lebih menekankan pada arti kemanfaatan (utility), kemungkinan dikerjakan (work ability), dan akibat yang memuaskan (satisfactory result) (Muhajir, 1999:14).

\section{Ranah Epistemologi dalam Paradigma Islam}

Akhir-akhir ini muncul banyak kegelisahan intelektual tentang urgensi dan utilitas ushul fikih dalam kajian keislaman. Kegelisahan tersebut diwujudkan dalam sebuah kecemasan bahwa ternyata sampai saat ini wajah usul fikih dan turunannya terasa kaku dalam menghadapi dan berkomunikasi dengan peradaban kekinian. Paling tidak kegelisahan tersebut dapat dilihat dari ekspresi intelektual muslim kontemporer, seperti misalnya Fazlu Rahman, berpendapat tidak lagi cukup memadai, lalu Muhammad Arkoun, Hassan Hanafi, Muhammad Syahrur, Nasr Hamid Abu Zaid, Ali Harb, dan Abdullahi Ahmed an-Nai'm (Abdullah, 2001:363).

Fazlur Rahman berpendapat tidak lagi cukup memadai untuk menggunakan teori fikih dan usul fikih tentang qath'iyyat dan dhanniyat. Dia menawarkan istilah ideal moral dan legal spesifik sebagai pembagian awal tradisi Islam (Rahman, 1982:13). Muhammad Arkoun menawarkan pemahaman ulang tentang tradisi Islam dengan membedakan secara tegas antara Turats (dengan $\mathrm{T}$ besar) dan turats (degan $\mathrm{t}$ kecil). Ia mempertanyakan semakin kaburnya dimensi tarikhiyyat (kesejarahan) dari keilmuan fikih. Ia juga mempertanyakan keabsahan pengekalan teori-teori fikih yang telah disusun beberapa abad lampau dan sampai sekarang masih terus diajarkan. Sementara poblematika dan tantangan pada era sekarang telah mengalami perubahan yang signifikan dari yang ada pada masa itu (Arkoun, 1986:172).

Hassan Hanafi menengarai perlunya sikap kritis terhadap tradisi kita dan tradisi mereka. Proyeknya yang terkenal al-turts wa al-tajdîd yang berupaya meletakkan landasan teoritis pada kerangka lingkaran piramida peradaban. Kerangka teoretis tersebut berisi bahwa manusia tidak bisa dipisahkan dari tiga akar pijakan berpikir; kemarin (al-madli), yang dipersonifikasikan dengan turats qadim (khazanah klasik). Esok (almustaqbal) yang dipersonifikasikan dengan turats gharbi (khazanah Barat), dan sekarang (al-hali), yang dipersonifikasikan dengan al-waqi' (realitas kontemporer) (Hanafi, 1989:7). Demikian juga dengan Muhammad Syahrur yang menawarkan teori bacaan kontemporer (Qira'ah Nu'ashirah), Nashr Hamid Abu Zaid dengan reinterpretasi teks suci, Ali Harb dengan teori dari 
kritik akal menuju ke kritik teks, dan Abdullahi Ahmad an-Na'im dengan teori naskh mansukh yang berbeda dari pemahaman umat selama ini (Syahrur, 1992; Zaid, 1990; An-Na'im, 1990).

Menarik apa yang dikembangkan oleh Muhammad Abid al-Jabiri yang berupaya merekonstruksi epistemologi studi keislaman dengan mensistematisir berbagai aliran pemikiran dalam sejarah Islam. Terdapat tiga aliran pemikiran Islam yang cukup menonjol dalam perkembangan intelektual ilmu-ilmu keislaman. Pertama, pemikiran filsafat yang jelas-jelas lebih menekankan pada penggunaan akal dan rasio dengan bukti-bukti yang nyata. Kedua, pemikiran kalam atau tauhid yang lebih menekankan pada teks-teks naqliah dengan sedikit bumbu aqliah. Ketiga, pemikiran tasawwufi yang lebih menekankan pada penggunaan rasa atau dzauq dengan bukti-bukti yang sulit dipertanggungjawabkan secara empiris (Fachry, 1989:75).

Model pertama dari ketiga ranah pemikiran di atas, paling tidak dapat dikategorikan sebagai paradigma burhani, karena lebih menekankan pada peranan rasio dan bukti empiris. Model kedua lebih cocok untuk dimasukkan dalam paradigma bayani, karena lebih menekankan pada peranan penjelasan terhadap otoritas nash dan teks suci. Sedangkan model ketiga lebih baik dimasukkan dalam paradigma irfani, karena lebih menekankan pada peranan intuisi, qalb, dlomir, dan dzauq (Al-Jabiri, 1990; 1991).

Trilogi epistemologi yang dikembangkan al-Jabiri tersebut di atas, telah mendapatkan respons positif dari para pemikir Muslim lainnya. Hal ini terbukti dengan adanya berbagai tanggapan bahkan elaborasi lebih jauh terhadap gagasan tersebut. Ide brilian al-Jabiri tersebut tidak menutup kemungkinan berimplikasi terhadap wilayah Islam, baik yang bersifat positif (memperluas wilayah) maupun yang bersifat negatif (mempersempit wilayah). Mengkaji ilmu-ilmu keislaman secara komprehensif dengan sendirinya akan menemukan ketiga ranah epistemologi tersebut. Karena pada dasarnya ketiga epistemologi tersebut sudah dilaksanakan dan dikembangkan oleh para ulama Islam selama ini. Dengan kata lain, upaya al-Jabiri tersebut merupakan usaha mensistematisasi berbagai metodologi pemikiran ilmu-ilmu keislaman yang sudah ada. Upaya tersebut sudah lebih dari cukup bagi perkembangan epistemologi ilmu-ilmu keislaman. Misalnya, ranah epistemologi bayani (retoris) yang telah menjadi pilihan utama bagi para ahli kalam selama ini. Untuk lebih jelasnya, dapat dikatakan bahwa epistemologi ranah bayani ini lebih mengedepankan pemahaman wahyu atau nash secara takstual. Atau dalam istilah Harun Nasution, "wahyu menguasai akal atau rasio" (Nasution, 1983:79).

Epistemologi yang demikian ini sangat menarik bagi para ahli kalam karena beberapa hal. Pertama, epistemologi ini tidak bersifat saling melengkapi akan tetapi lebih banyak bersifat dialogis dan lebih-lebih polemis. Dengan kecenderungan untuk tidak saling melengkapi atau 
bahkan cenderung polemis, sebagai akibatnya terjadi klaim sepihak terhadap pihak lain yang berbeda pandangan atau bertentangan sama sekali. Kedua, meskipun terdapat ahli kalam yang mengedepankan akal, akan tetapi pada titik tertentu masih memanfaatkan atau bahkan memanipulasi wahyu dengan memberikan interpretasi sebaliknya dari interpretasi pihak lain atau lawan. Intrpretasi yang bertolak belakang terhadap wahyu bukan sebagai upaya untuk melepaskan akal darinya, akan tetapi lebih dimaksudkan sebagai counter bagi pihak lain yang berseberangan paham. Ketiga, ahli Qalam lebih suka menggunakan analisis yang bersifat retoris sebagai upaya untuk memberikan balance atau bahkan mengalahkan pihak lain. Kritik-kritik yang disampaikan tidak berupaya mencari titik temu di antara mereka, akan tetapi justru untuk menunjukkan hegemoni salah satu diantara mereka. Dan keempat, sebagai upaya untuk membela diri baik karena jauhnya jarak, tingkat pemahaman, atau referensi yang digunakan.

Dengan demikian, semua kecenderungan yang demikian ini akan menjadi polemik yang berkepanjangan, manakala tidak ada satu pun ulama yang berupaya merekonstruksi epistemologi ilmu-ilmu keislaman. Maka, sebagai penyeimbang adanya epistemologi bayani muncullah epistemologi burhani (demonstratif). Epistemologi burhani (demonstratif) ini lebih bersifat rasional, karena sarana utama dalam eksplorasinya menggunakan akal atau rasio. Dalam hal ini, nilai-nilai wahyu yang terinternalisasi dalam diri pakar juga memiliki peranan yang cukup penting. Artinya epistemologi ini meskipun lebih cenderung liberal, akan tetapi masih ada sekat-sekat nilai wahyu yang telah diyakini pakar tersebut. Dalam perjalanan sejarah peradaban Islam, epistemologi ilmu-ilmu keislaman ini lebih digandrungi oleh para filosof.

Para filosof lebih cenderung menggunakan epistemologi burhani (demonstratif) disebabkan oleh beberapa hal. pertama, filosof tidak mau terjebak dalam logika bahasa Arab yang cenderung memisahkan antara perbuatan dan waktu. Dalan logika bahasa Arab dikenal istilah fi'il madly untuk perbuatan masa lampau, dan fi'il mudhari' unuk perbuatan masa sekarang ini atau masa yang akan datang. Implikasi dari logika ini adalah bahwa perbuatan yang sama memiliki waktu yang berbeda. Kedua epistemologi burhani member ruang yang sangat luas bagi pengembangan intelektual mereka. Batasan-batasan wahyu bukan datang dari teks-teksnya, melainkan dari nilai-nilai wahyu yang telah ada secara inheren dalan diri para filosof. Mereka tidak segan-segan memberi interpretasi yang berbeda atau bahkan bertntangan dengan arti harfiyah teks wahyu, sebagai akibat luasnya ruang kebebasan intelektual. Dan ketiga, epistemologi ini lebih meyakinkan secara inderawi. Untuk menciptakan sebuah ilmu yang sahih dan valid memerlukan kebenaran koherensi antara realitas (alam, manusia, Tuhan) dengan akal. Ilmu yang pada dasarnya adalah sekumpulan kebenaran yang tersusun secara sistematis, perlu sekali mendapatkan legalitas inderawi dan rasionalitas. Dengan demikian, ia tidak hanya 
terjebak pada tingkat retorika yang sewaktu-waktu bisa berubah sesuai dengan subyektivitas pakar.

Ada satu hal yang sangat menarik antara dua epistemologi di atas, yaitu terjadinya analogi burhan dalam tradisi bayan, khususnya dalam ilmu balagah. Telah menjadi maklum bahwa ilmu balaghah memiliki tiga unsur utama, yaitu bayan, ma'ani dan ba'di. Dalam kajian ilmu bayan yang menjadi idola pembahasan adalah tasybîh, yaitu mengalihkan perhatian pembaca atau lawan bicara dari sesuatu hal yang ma'qûl (bisa diterima akal) ke sesuatu yang bersifat inderawi, atau menggambarkan sesuatu yang majhul (tidak dikenal) dengan sesuatu yang ma'lum (yang sudah dikenal). Sedangkan isti'ârah (peminjaman arti) dan kinâyah (makna kiasan) pada dasarnya masuk dalam kategori tasybih. Bila terjadi sesuatu yang diserupai tersebut masih majhul atau ma'qul, maka masih memerlukan interpretasi yang bersifat inderawi dan dapat dikenal (Al-Jabiri, 2000:82). Sebagai contoh, sebagaimana dikemukakan al-Jahiz dalam memahami firman Allah yang membingungkan orang-orang Arab: "sesungguhnya dia (pohon zaqqum yang ada dalam neraka) adalah sebatang pohon yang keluar dari dasar neraka jahim. Mayangnya seperti kepala syaitan-syaitan". Menurut mereka (orang-orang Arab), kepala syaitan-syaitan (ru'us syayathin) adalah wujud yang tidak diketahui dan tidak bisa ditangkap indera manusia. Padahal dalam ayat ini ia dijadikan sebagai sesuatu yang diserupai, maka sebagai jalan keluarnya, mereka menganggap ru'us syayathin itu sebagai pohon yang tumbuh di negeri Yaman. Hal ini dimaksudkan agar tetap konsisten dalam aturan-aturan tasybih dan analogi atau bayan dan burhan. Dengan demikian telah terjadi penggunaan metodologi burhan dalam tradisi bayan (Al-Jabiri, 2000:83).

Selanjutnya epistemologi irfani (gnostik) lebih bersifat afektif dan eksperiensif, karena unsur utama yang mendukung epistemologi ini, perasaan atau dzauq. Pengalaman seseorang akan menjadi model ajaran dirinya, di mana kebenaran yang dia peroleh sesuai dengan pengalaman pribadi yang kadang-kadang sangat sulit untuk dipahami atau diterima pihak lain. Sejarah umat Islam membuktikan bahwa ranah epistemologi ini lebih dinikmati para sufi, khususnya yang sudah berada pada tingkat tinggi. Kenikmatan yang dirasakan para sufi dengan epistemologi ini bisa mencapai sikap pengorbanan dari mereka. Pengorbanannya sangat besar, sampai nyawa dirinya dipertaruhkan untuk mempertahankan kebenaran atau kenikmatan yang dialaminya. Epistemologi gnostik menjadi andalan para sufi dikarenakan beberapa hal. Pertama, adanya keyakinan bahwa manusia memiliki dua dimensi yang inheren di dalam dirinya, yakni dimensi ilahiyah (lahut) dan insaniyah (nasut). Dalam upaya mendekatkan diri kepada Tuhan, manusia harus menghilangkan sifat nasut-nya. Sedangkan instrumen manusia yang bersifat lahut adalah $d z a u q$ atau perasaan, sehingga menjadi sangat tepat bila para sufi suka menikmati epistemologi irfani. Kedua, pengalaman memegang peranan yang sangat penting dalam tradisi 
para sufi. Pengalaman yang dialami para sufi dilalui dengan pengerahan seluruh potensi manusia, temasuk perasaan. Bahkan kadang-kadang sampai kehilangan kesadaran (yang bersifat rasional) akan eksistensi dirinya. Dan ketiga, kecintaan akan Tuhannya, menjadikan para sufi hanya memetingkan kepentingan dan kebutuhan ruhani. Kebutuhan ruhani hanya dapat terpenuhi melalui cara-cara dan dengan perangkat yang bersifat ruhani juga, sehingga sebagai upaya untuk mendapat cinta Tuhannya, mereka tidak lagi menggunakan bahasa rasional maupun bahasa ujaran, tetapi yang mereka gunakan adalah bahasa perasaan, bahasa hati nurani, dan bahasa ruhani. Dalam hal ini adalah dengan dzauq atau irfan.

Ketiga paradigma di atas menjadi lebih memikat ketika dikaitkan dengan usul fikih yang pada dasarnya bersumber dari teks-teks suci dan nash-nash Illahi. Sebagaimana dikemukakan pada awal tulisn, bahwa ushul fikihh tidak dapat dilepaskan dari ketiga jenis pengetahuan manusia. Usul fikih tidak dapat disamakan dengan fikih atau hokum Islam yang sudah ada. Hal ini didasarkan pada beberapa alasan. Pertama ushul fikih dengan fikih berbeda dari segi istilah. Usul fikih terdiri dari dua terma yaitu ushûil dan figh, sementara figh hanya terdiri atas satu terma yaitu figh. Fikih dalam pemahaman umum dikatakan sebagai ilmu pengetahuan tentang hukumhukum syar'i yang diturunkan (diperoleh) dari dalil-dalil khusus (AlZarqa', 1978:54). Berbeda dengan usul fikh yang didefinisikan sebagai pengetahuan tentang kaidah-kaidah dan pembahasan-pembahasan yang dijadikan sebagai acuan dalam menetapkan hukum syar'i mengenai perbuatan manusia berdasarkan dalil-dalil yang terinci (Khallaf, 1978:7). Kedua, usul fikih merupakan kaidah-kaidah yang menyangkut hal-hal yang bersifat umum (kulli), sedangkan fikih berisi pemahaman terhadap masalahmasalah yang bersifat parsial (juz'i). Ketiga, usul fikih menjadi induk dan landasan bagi pengambilan hukum dari dalil-dalil, sedangkan fikih merupakan produk hukum yang diambil dari dalil-alil tersebut. Dengan demikian, sangat jelas bahwa perbedaan antara usul fikih dan fikih tidak mungkin dipisahkan atau dipungkiri.

Dengan kata lain, trilogi epistemologi al-Jabiri dalam dunia usul fikih sebenarnya akan menjadi lebih berarti. Sebagaimana disinyalir oleh Hassan Hanafi bahwa usul fikih merupakan salah satu turats atau tradisi lama Islam yang harus dilakukan rekonstruksi dari teks ke realita (min al-nash ila alwaqi': muhawalah li I'adah bina' ilm usûl figh) (Hanafi, 1980:213). Karenanya dibawah ini akan diungkap sedikit tentang bagaimana upaya rekonstruksi usul fikih tersebut dalam paradigma kontemporer.

\section{Ushul Fikih dalam Bingkai Trilogi Epistemologi al-Jabiri}

Usul fikoh bagi sebagian ulama dianggap sebagai diskursus yang hanya membicarakan tentang hukum-hukum yang bersifat doktrinal. Padahal bila seseorang mengkaji lebih mendalam ternyata usul fikih tidak sesederhana itu. Paling tidak dalam hal ini bisa sitinjau dari tiga sudut pandang. Pertama, sudut pandang ilmu-ilmu keislaman lainnya. Kedua sudut 
pandang ruang lingkup. Dan ketiga, sudut pandang aplikasinya dala masyarakat Islam. Ditinjau dari ilmu-ilmu keislaman lainnya dapat dilihat dari berbagai ilmu yang menjadi kolega atau turunan dari usul fikoh itu sendiri. Misalnya, usul fikih bila dikaitkan ilmu ushâl al-dîn (teologi), ia menduduki posisi yang sangat strategis. Bila ushâl al-dîn merupakan dasardasar utama agama, maka usul fikih adalah dasar-dasar hukum. Sedangkan hukum itu sendiri bersifat multidimensional. Memang ushuluddin adalah pokok-poko agama, akan tetapi lebih cenderung bersifat idelistik dan spiritual murni. Demikian juga tasawwuf lebih bersifat transendental dan esoterik. Sedangkan usul fikih yang menjadi dasar-dasar hukum berdimensi sosial, historis, kultural, ideologis, geografis, bahkan etnografis.

Usul fikih dalam hubungannya dengan tafsir, nahwu, dan sastra juga memiliki relasi yang sangat kuat. Artinya usul fikih pada intinya adalah penafsiran ulang terhadap seluruh kajian teks-teks suci Alqur'an dengan menggunakan berbagai pendekatan. Misalnya pendekatan bahasa, pendekatan logika, bahkan teologi. Ini sebuah perkembangan usul fikih bersimbiosis mutualisme dengan ketiga ilmu di atas. Usul fikih juga memberikan konstribusi bagi perkembangan dan diversifikasi ilmu tafsir. Hal ini dibuktikan dengan munculnya kajian tentang tafsir ahkam yang pada giliran selanjutnya memunculkan teori-teori usul fikih. Tidak dapat dipungkiri, bahasa dan sastra juga memiliki keterikatan dengan usul fikih, karena perkembangan ilmu bahasa dan sastra juga berbanding lurus dengan pertumbuhan dan perkembangan ilmu usul fikih.

Usul fikih dalam hubungannya dengan fikih, dapat dikatakan bahwa usul fikih merupakan sebuah epistemologi tersendiri bagi fikih. Ungkapan seperti ini pernah disinyalir Muhammad Arkoun (1988:62). Usul fikih bagi fikih memiliki kedudukan yang sangat dominan. Salah satunya adalah sebagai dasar-dasar kaidah yang harus diperhatikan dalam menentukan hukum dari suatu persoalan. Di samping itu, usul fikih juga dianggap sebagai metodologi penetapan hukum. Sebagai sebuah metodologi, usul fikih seharusnya lebih bersifat terbuka dan fleksibel. Perkembangan dan keluwesan hukum Islam sangat ditentukan oleh paradigma usul fikihnya. Selain kedudukan di atas, usul fikih juga dianggap sebagai epistemologi hukum Islam. Sebagai sebuah epistemologi, usul fikih sudah cukup memadai.

Ditinjau dari ruang lingkup, usul fikih memiliki cakupan yang sangat luas. Seluruh perbuatan manusia menjadi obyek kajiannya. Seperti dapat di lihat dalam materi kajian fikih mulai dari yang klasik sampai kontemporer, betapa seluruh aspek kehidupan manusia tercakup di dalamnya. Dengan kata lain, segala aktivitas manusia baik yang berhubungan dengan diri sendiri, orang lain, masyarakat, lingkungan dan Tuhan semua ter-cover dalam fikih. Bila fikih itu sendiri memiliki cakupan yang sangat luas, dengan sendirinya usul fikih sebagai kaidah-kaidah dasar 
yang menjadi acuan bagi penetapan hukum memiliki ruang lingkup yang lebih besar.

Dari sudut pandang aplikasi dalam kehidupan masyarakat, ushul fiqh jelas sangat dekat. Berbagai kajian tentang usul fikih ujung-ujungnya adalah pelaksanaan hukum dan kehidupan manusia. Seperti halnya ruang lingkup usul fikih, aplikasinya dalam masyarakat menajdi penentu bagi keberhasilan usul fikih itu sendiri. Artinya, aplikasinya dalam masyarakat dapat dijadikan sebagai tolak ukur keberhasilan usul fikih. Di era kentemporer ini, tentunya usul fikih perlu ditata dan dibaca ulang, sebagai salah satu cara untuk maningkatkan fleksibilitas dan keterbukaan dirinya. Perkembangan peradaban, ilmu pengetahuan dan teknologi menuntut adanya pemahaman, pembacaan dan paradigma baru dalam usul fikih, paling tidak dasar-dasar epistemologisnya perlu di-match-kan dengan kemajuan ilmu pengetahuan dan teknologi yang paling mutakhir.

Pengembangan hukum Islam harus selalu up to date dan fleksibel dalam perkembangan zamannya. Karena itu, ia dituntut memiliki dasardasar epistemologis yang fleksibel juga. Untuk memenuhi tuntutan teori epistemologis usul fikih harus dilihat dari tiga hal, yaitu hakikat, sumber, metode. Ketika ushul fiqh bisa dilihat dari ketiga hal di atas dan memenuhi persyaratan, ia layak dimasukkan dalam kategori ilmiah (meskipun ilmiah dalam ranah epistemologi Islam). Hakikat usul fikih itu sendiri dapat dilihat dari pengrtiannya. Seperti diungkap di atas, usul fikih adalah pengetahuan tentang kaidah-kaidah dan pembasahan-pembahasan yang dijadikan sebagai acuan dalam menetapkan hukum syar'i mengenai perbuatan manusia berdasarkan dalil-dalil yang terinci. Dari definisi tersebut paling tidak dapat diambil beberapa pemahaman, yaitu:

1. Usul fikih adalah sekumpulan pengetahuan. Usul fikih merupakan sejumlah pengetahuan yanng telah tersistematisir dengan baik dan telah berjalan dengan waktu yang cukup lama. Pengetahuan dalam hal ini tentunya telah melewati uji kebenaran (verifikasi) dan uji kesalahan (falsifikasi) dari berbagai pihak, baik yang mendukung atau bahkan yang menolak. Sebagai jumlah pengetahuan, maka dia bersifat terbuka dan menjadi konsumsi bagi siapa saja yang berminat untuk memahami, mendalami, mengkritisi atau menolak. Hanya saja dalam tradisi Islam ikatan emosional maupun moral keagamaaan tidak akan dipisahkan dari setiap personnya.

2. Usul fikih merupakan sejumlah kaidah-kaidah yang bersifat umum. Kaidah dalam kegiatan dunia ilmu bisa dianggap sebagai kesepakatan umum, meskipun tidak bersifat mengikat. Sebagai sebuah kaidah, usul fikih dengan sendirinya akan menurunkan beberapa teori, khususnya yang berkaitan erat atau memiliki obyek yang sama. Karena sifatnya yang umum atau universal, maka usul fikih paling tidak harus mengakomodir berbagai perbedaan yang disebabkan pebedaan ruang dan waktu. 
3. Usul fikih merupaka acuan yang digunakan dalam menetapakan hukum syar'i mengenai perbuatan manusia. Hukum Islam yang dipakai dan dilaksanakan oleh umat Islam harus mengacu pada usul fikih. Dengan kata lain, produk hukum yang berlaku dari era klasik sampai era modern ini harus mengacu pada usul fikih yang telah diintrodusir para ulama fikih. Sebagai kosekuensi logisnya, seorang muslim yang memiliki otoritas dan kedudukan dalam penetapan hukum Islam, harus memahami dan menggunakan usul fikih. Artinya usul fikih harus dikuasai oleh pihak-pihak yang dipercaya sebagai pengambil keputusan hukum Islam.

4. Usul fikih diambil dari dalil-dalil yang terinci. Usul fikih bukanlah pengetahuan yang diciptakan oleh manusia, akan tetapi merupakan pengetahuan yang ditemukan oleh para pakar dan ahli dari dalil-dalil Alqur'an dan Sunnah. Artinya usul fikih tidak boleh keluar dari koridor keduanya, meskipun akhir-akhir ini banyak kritikan terhadap kemurnian Sunnah. Dengan demikian usul fikih bukanlah pengetahuan yang datang secara tiba-tiba, melainkan dihasilkan dari perenungan dan pendalaman yang maksimal terhadap dalil-dalil yang ada.

Kriteria selanjutnya sebagai sebuah entitas ilmiah, usul fikih dapat dilihah dari sumbernya. Sumber usul fikih adalah nash-nash Alqur'an, nashnash kauniyah (alam semesta), nash-nash ijtima'iyah (sosial masyarakat), dan nash-nash wujdaniyah (hati nurani dan spiritualitas diri manusia). Alqur'an adalah sumber materi usul fikih yang dapat langsung dibaca dari teks-teks suci. Sumber inilah yang menempati porsi yang paling besar dalam khazanah intelektual usul fikih. Hal ini wajar, karena secara tekstual semua orang mampu mengakses dan memahaminya. Berbeda dengan nash-nash kauniyah yang tidak semua orang mampu memahami dan mengartikulasikan dalam kajian usul fikih. Namun demikian, terdapat sebagian orang yang ahli dan mendalam pemahamannya tentang nash-nash kauniyah. Nash-nash kauniyah ini dijadikan sumber usul fikih, karena pada dasarnya sumber pegetahuan bukan hanya dapat diperoleh dari teks-teks konvensional yang tersusun secara rapi dalam korpus-korpus masa lalu. Demikian juga dengan sumber nash-nash ijtima'iyah dan nash-nash wujdaniyah. Usul fikih kontemporer menjadikannya sebagai sumber, karena pada dasarnya fenomena individual yang bersifat psikologis, psikogenesis, dan sosial, baik berupa struktur maupun kultur masyarakat tidak dapat diabaikan. Perubahan dan perkembangan peradaban manusia pada intinya adalah adanya perbedaan antara individu dan sosial dalam berbagai aspeknya.

Selanjutnya, sebagai pemenuhan kriteria epistemologi yang ketiga yaitu tentang metode. Usul fikih dalam perjalanan sejarahnya telah memiliki metode yang berbeda. Berbagai pendekatan telah dimunculkan. misalnya: pendekatan bi dalalat al-nash dan bi al-ra'yi; pendekatan tekstual dan kontekstual; pendekatan bayani, ta'lili, dan istislahi. Metode-metode tersebut 
menunjukkan terjadinya dialektika dari berbagai unsur dan struktur ilmu pengetahuan yang mengiringi, ketika metode tersebut dimunculkan. Sebagai sebuah disiplin ilmu yang fleksibel dan terbuka, dengan sendirinya usul fikih menerima realitas seperti itu. Pemahaman ulang terhadap teksteks suci tidak terlelakkan lagi. Namun demikian teks-teks tersebut tetap menjadi salah satu acuan selain teks-teks yang lain (teks kauniyah, ijtima'iyah, dan wujdaniyah).

Dalam kaitannya dengan trilogi epistemologi al-Jabiri, maka usul fikih berada diluarnya. Memang al-Jabiri secara umum memasukkan teologi dan fikih dalam epistemologi bayani. Hal ini didasarkan pada kenyataan bahwa pendekatan bi dalalah al-nash, tekstual, atau bayani menempati posisi utama dalam kajian usul fikih. Namun demikian, pada kenyataannya, pendekatan di atas bukanlah satu-satunya pendekatan yang ada dalam usul fikih. Karena ternyata masih ada pendekatan lain, apalagi dilihat dari sumber usul fikih itu sendiri. Sangat tidak memadai bila usul fikih hanya dimasukkan pada epistemologi bayani sebagaimana yang dipahami alJabiri. Benar, Pemahaman fikih oleh al-Jabiri dikategorikan dalam epistemologi bayani, namun sebagaimana diungkap di atas, fikih jelas berbeda dengan usul fiikihh. Yang pertama adalah produk sementara, dan yang kedua adalah kaidah-kaidah dalam menentukkan produk tersebut. Dengan demikian, keduanya tidak mungkin disamakan atau dianggap sama. Keduanya jelas berbea akan tetapi memiliki hubungan yang sangat erat.

Dimasukkan dalam kategori epistemologi irfani, usul fikih juga sangat susah. Karena usul fikih tidak hanya berurusan dan bersumber dari hal-hal yang bersifat wujdani. Memang itu merupakan salah satu sumber usul fikih, akan tetapi bukanlah satu-satunya. Usul fikih sangat erat hubungannya dengan interaksi yang bersifat horizontal, sekaligus vertikal. Bahkan interaksi yang bersifat sirkular. Artinya, kajian usul fikih mencakup hubungan antara manusia dengan Tuhannya, dan hubungan antara manusia dengan dirinya sendiri.sebagai konsekuensi logisnya ushul fiqh tidak bisa menghindari atau bahkan membuang salah satu bentuk hubungan interaksi di atas.

Apabila dimasukkan dalam epistemologi burhani juga kurang memadai. Sebagaimana dalam pemahaman al-Jabiri tentang epistemologi burhani ini yang dijadikan sebagai sumber adalah realitas alam, sosial, dan humanitas. Metode yang dapat dikembangkan adalah abstraksi dan analisis. Pendekatan yang sering digunakan adalah filosofis dan saintifik. Usul fikih dalam hubungannya dengan epistemologi ini, secara nyata memang tidak dapat dipisahkan. Karena memiliki sumber yang sama. Akan tetapi sekali lagi, usul fikih tidak hanya berbicara dan bersumber dari realitas alam, sosial dan humanitas belaka. Ushul figh tidak akan mampu melepaskan diri dari ayat-ayat Alqur'an dan pengetahuan Tuhan yang dapat diperoleh melalui wujdan dan hati nurani manusia. Dengan demikian kurang pas bila hanya dimasukkan dalam epietemologi ini. 
Barangkali usul fikih cukup layak untuk dijadikan sebagai sebuah epistemologi tersendiri yang mencakup ketiga epistemologi al-jabiri di atas. Dalam hal ini bisa disebut dengan epistemologi jama'i atau epistemologi komprehensif. Artinya, ushul fikih merupakan sebuah epistemologi tersendiri yang disebut dengan epistemologi komprehensif atau epistemologi jama'i. Hal ini didasarkan pada asumsi bahwa hakikat usuul fikih adalah sejumlah pengetahuan yang tersusun secara rapi berupa kaidah-kaidah umum sebagai acuan penetapan hukum tentang segala perbuatan manusia. Sumber usul fikih adalah nash Alqur'an, nash kauniyah, nash ijtima'iyah, dan nash wujdaniyah. Dan metode yang digunakan dalam usul fikih mencakup metode bi dalalah al-nash dan al-ra'yi; tekstual dan kontekstual; bayani, ta'lili, dan istislahi. Melihat epistemologi seperti ini maka layak dipahami bahwa sebenarnya logika Islam itu sendiri adalah ushul fiqh.

\section{Kesimpulan}

Berdasarkan uraian tersebut di atas, maka dalam akhir tulisan ini dapat disimpulkan hal-hal sebagai berikut:

Pertama, usul fikih sebagai ilmu yang memproduksi hukum Islam banyak dicemaskan oleh para intelektual Islam kontemporer, antara lain: Fazlur Rahman, Muhammad Arkoun, Hassan Hanafi, Muhammad Syahrur, dan Hamid Abu Zaid. Hal ini karena usul fikih tidak fleksibel dalam menghadapi problematika kekinian. Untuk itu mereka menyusun teori-teori baru yang dipandang dapat dijadikan solusi dalam berbagai permasalahan sosial.

Kedua, Muhammad Abid al-Jabiri, seornag intelektual kontemporer, berupaya merekonstruksi epistemologi studi keislaman dengan mensistimatisir berbagai aliran pemikiran Islam. Tiga paradigma pemikiran Islam, burhâni, bayani dan 'irfani diintegrasikan dan dielaborasi lebih lanjut untuk menemukan formula baru dalam kajian usul fikih kontemporer, yang pada gilrannya penggabungan ini disebut dengan epistimologi jama' $i$, karena usul fikih merupakan himpunan dari sejumlah pengetahuan yang tersusun secara rapi untuk menemukan hukum-hukum Islam.

Ketiga, usul fikih dalam tilikan foilosofis mengandung beragam pandangan. Paling tidak, bila dilihat dari sudut epistemologis. Epistemologi yang berkembang dalam perjalanan intelektual umat Islam tidaklah sesederhana yang dibayangkan orang, meskipun dalam perkembangan akhir-akhir ini, nampaknya, epistemologi usul fikih kurang diperhatikan atau bahkan ingin dicampakkan dengan alasan ketakutan akan kehancuran usul fikih itu sendiri, paling tidak ia tetap mendapat sambutan cukup meriah dari para pakar fikih. Dengan demikian, menjadi sangat wajar ketika para pengkaji usul fikih di berbagai perguruan tinggi Islam, dituntut untuk senantiasa berinovasi dan mengeksplorasi gagasan tentang usul fikih sebagai logika Islam atau bahkan epistemologi jama'i-nya. 


\section{DAFTAR PUSTAKA}

Abdullah, Amin, "Ke arah Perubahan Paradigma Penafsiran Kitab Suci", dalam al-Jami'ah: Jornal of Islamic Studies, Yogyakarta, Vol. 39, No. 2, Juli-Desermber 2001

Anshari, Endang Saefudin, Ilmu Filsafat dan Agama, Surabaya, Bina Ilmu, $1991 \mathrm{M}$

Arkoun, Muhammad, al-Islâm : al-Akhlâq wa al-Siyâsah, Beirut : Markaz alInma' al-Qaumi, 1986

- Muhammad, "The Consept of Authority in Islamic Thought", dalam Klaus Ferdinand and Mahdi Mozaffari, (ed.), Islam : State and Society, London: Curzon Press, 1988 M

Bakhtiar Amtsal, Filsafat Agama, Jilid I, Jakarta : Logos, 1997 M

Fachry, Madjid, Khazanah Intelektual Islam, alih bahasa oleh Mulyadi Kartanegara, Jakarta: Bulan Bintang, 1989

Ghazali al-, Abû Hâmid, al-Mustasyfâ min 'Ilm Ushûl al-Fiqh, Kairo: Syirkah al-Thiba'ah al-Fanniyah al-Muttahidah, $1979 \mathrm{M}$

Hadiwiyono, Harun, Sejarah Filsafat Barat, I, dan 2, Yogyakarta: Kanisius, $1991 \mathrm{M}$

Halmyn, D.W. "History of Epistimology", dalam Paul Edward, (ed.), The Encyclopedia of Philosophy, New York: MacMillen, 1972 M

Hanafi, Hassan, al-Dîn wa al-Tsawrah, Vol. I, Kairo: Madbouly, 1989 M $1980 \mathrm{M}$ Mauqifuna min al-Turâts al-Qadîm, Kairo: al-Markaz al-'Arabi,

Jabiri, Muhammad Abid al-, Bunyah al-'Aql al-'Arabi, Beirut: Markaz Dirâsah al-Wihdah al-'Arabiyyah, 1990 $1990 \mathrm{M}$ Takwîn al-'Aql al-'Arabi, Beirut: al-Markaz al-Tsaqafi al-'Arabi, al-'Aql al-Siyâsi al-'Arabi, Beirut, al-Markaz al-Tsaqafi al-' Arabi, $1991 \mathrm{M}$

Post Tradisionalis Islam, alih bahasa oleh Ahmad Baso, Yogyakarta, LkiS, 2000

Jurjani al-, al-Ta'rifat, ttp: al-Dâr al-Tunisiyyah li al-Nasyr, 1971 M 
Nasution, Harun, Teologi Islam: Aliran-Aliran Sejarah Analisa Perbandingan, Jakarta, Universitas Indonesia Press, 1983 M

Kattsof, Louis O, Pengantar Filsafat, alih bahasa Soerjono Soemargono, Yogyakarta: Tiara Wacana, $1989 \mathrm{M}$.

Muhajir, Noeng, Filsafat Ilmu: Telaah Sistematis Fungsional Komparatif, Yogyakarta: Rake Srasin, 1999 M

Na'im, Abdullai Ahmad An-, Toward an Islamic Reformation: Civic Liberties, Human Right, and International Law, New York: Syracuse University Press, $1990 \mathrm{M}$

Rahman, Fazlur, Islam and Modernity : Transformation of an Intelectual Tradition, Chicago: The University of Chicago Press, $1982 \mathrm{M}$

Suriasumantri, Jujun S, Filsafat Ilmu: Sebuah Pengantar Populer, Jakarta: Logos, $1997 \mathrm{M}$

\section{M}

Syahrur, Muhammad, al-Kitâb wa al-Qur'ân, Kairo: Sina Publisher, 1992 M

Syirazi, Abû Ishâq Ibrahim ibn 'Ali, al-Luma' fi Ushûl al-Fiqh, Kairo: Muhammad 'Ali al-Shabih, $1990 \mathrm{M}$

Tafsir, Ahmad, Filsafat Umum: Akal dan Hati Sejak Thales sampai James, Bandung: Remaja Rosdakarya, 1999 M

Taryadi, Alfons, Epistemologi Pemecahan Masalah Menurut Karl. R. Popper, Jakarta: Gramedia, 1991 M

Titus, Harold H., Persoalan-Persoalan Filsafat, alih bahasa oleh H. Muhammad Rasyidi, Jakarta: Bulan Bintang, 1984 M

Zaid, Nashr Hamid Abu, Mafhûm al-Nash: Dirâsat fì 'Ulûm al-Qur'ân, Kairo: al-Hai'ah al-Mishriyyah al-Ammah, $1990 \mathrm{M}$

Naqd al-Khithâb al-Dini, Kairo: Sina li Nasyr, 1994 M

Harb Ali, Naqd al-Nash, Beirut: al-Markaz al-Tsaqafi al-'Arabi, 1993 M

Zarqa' al-, al-Figh al-Islâmi fì Saubih al-Jadîd, Jilid I, Damaskus: Dâr al-Fikr, $1968 \mathrm{M}$

Ziai, Hossein, Suhrawardi dan Filsafat Illuminasi: Pencerahan Ilmu Pengetahuan, alih bahasa oleh Afif Muhammad dan Munir, Bandung: Zaman Wacana Mulia, 1998 M. 
